\title{
Faking It: A Case of Counterfeit Possession in the Reign of James $\mathrm{I}^{1}$
}

\section{RICHARD \\ RAISWELL}

Résumé : En 1622, au printemps, l'adolescente Katheren Malpas, sa mère et ses grands-parents du côté maternel ont été inculpés dans le Star Chamber pour avoir cyniquement organisé une possession démoniaque frauduleuse afin de profiter de la charité de leurs voisins. En puisant dans le procés-verbal détaillé, le présent article reconstruit le mécanisme de l'imposture et attribue son écroulement à une tension épistémologique. Les comploteurs ont été coincés entre les exigences du discours démoniaque populaire et le besoin, de plus en plus imposé par l'état depuis le cas notoire de Mary Glover, de fournir des preuves des phénoménes surnaturels. D'ailleurs, la composition sociale changeante de la paroisse, qui autrefois était largement rurale, faisait en sorte qu'ils avaient deux publics à satisfaire simulanément. De cette contradiction inhérente dans leur entreprise découlait son échec.

Tn the spring of 1622 , Thomas Saunders, described as a yeoman of Upton, in the parish of West Ham, Essex, his wife Elizabeth and their daughter Katheren Malpas Senior were examined in Star Chamber in front of Sir Thomas Coventry, the Attorney General. ${ }^{2}$ The three of them were charged with persuading, procuring and inciting Katheren Malpas the younger - the daughter of Katheren Malpas Senior - "to counterfeite and fayne her selfe to be bewitched and possessed with an evill spirite, and to counterfeite and faiyne certaine strange fitts and traunces"3 (STAC 8 32/13 f. 18). While cases of counterfeit possession were not uncommon in the later Tudor and early Stuart period, what is unusual here is that Elizabeth Saunders admitted that she concocted the whole scheme "to gayne \& gett money for the better 
mantaynance of the Aforesaid Katheren Malpas the younger her mother \& sister \& not for any other intent or purpose" (STAC $832 / 13 \mathrm{f} .12^{\mathrm{r}} \mathrm{q}$. 14). But given that the Attorney General seems to have been prepared to accept that the sums garnered were small, and likely completely off-set by the expenses incurred trying to publicise the case, why did this petty fraud end up being heard in front of one of the highest courts in the country?

\section{I}

Demonological possession is a curious issue. Although modern epistemology has little place for supernatural causation, most people of early seventeenth-century England believed it to be a physical possibility confirmed both by Scripture and historical precedent. As a valid and sufficient explanatory category for a series of closely-defined phenomena, possession served as a fundamental intellectual filter through which men and women thought. By asking how and in what context they came to diagnose possession and by assessing how people peripheral to the central drama reacted to such instances, it is possible to reconstruct an important part of their intellectual apparatus and to catch a glimpse of the social dynamics which facilitated and fostered such a mode of explanation. From this perspective, then, possession can be treated as a cultural product, taking its meaning and content from the more general intellectual and social structures of society. Thus, a close analysis of instances of possession ought to highlight some of the fundamental intellectual preconditions of causality in popular physics and metaphysics. ${ }^{4}$ Unfortunately, though, the extant record does not easily lend itself to such a mode of analysis.

Hitherto, the historiography of possession and the ancillary field of witchcraft in England has relied heavily on contemporary pamphlets and court records. However, as sources for intellectual culture, both are somewhat deficient. In the first place, pamphlets written about particularly infamous demoniacs or witches are frequently highly sensational. While they generally purport to represent events as closely as possible, they were printed primarily to sell. As such, didactic morality and the need for sensational drama may well colour significant portions of the text in ways which are not readily apparent. James Cockburn has found serious discrepancies between the pamphlet account of the trial of Agnes Waterhouse in 1566 and the assize record of the case, despite the fact that the author of the pamphlet assures the reader that his account is "verbatum as nere as coulde be gathered." 5 
On the other hand, the legal record is equally problematic. Although a large number of witchcraft indictments survive from the Elizabethan and Jacobean periods, these are generally vague and formulaic and limit themselves primarily to the names and occupations of the parties, together with the date and place of the alleged offence. Where the felony itself is described, this is generally done very superficially and only insofar as the specific details are relevant to the charge. Yet even some of these basic details seem to have been manufactured by over-anxious clerks, for it was not uncommon for indictments deficient in any of the details prescribed by common law to be rejected by assize judges. ${ }^{6}$ As a result, the indictment records lend themselves only to large-scale statistical analyses like that done for Essex by Alan Macfarlane. While this analysis has allowed Macfarlane to develop a portrait of the archetypal Essex witch and has helped him assess the context in which she came to the attention of the authorities, ${ }^{7}$ it says little about the social or intellectual situation which caused the witch's contemporaries to resort to a supernatural discourse to explain her actions. Moreover, such an approach yields nothing about the actual content of this discourse. In the context of a crime in which so much must have occurred only in the mind, this is surely quite an acute problem.

In contradistinction to these sources, the records of the Jacobean court of Star Chamber offer a largely unexplored opportunity. While the court was widely criticised by contemporaries for its inquisitorial procedure, its records are consequently unusually rich in detail, for defendants were obliged to supply written answers to each specific point in the interrogatories posed to them. Indeed, of the three phases of a Star Chamber trial, the first two had to be written. Moreover, as was not the case with proceedings at common law, defendants had to furnish their answers under oath. ${ }^{8}$ But because Star Chamber was a prerogative court and tended to deal with cases for which there was no statutory provision, only four witchcraft-related trials were held in the Star Chamber under James. ${ }^{9}$ Of these, the approximately twelve-hundred lines of text outlining the case against Thomas and Elizabeth Saunders and their daughter Katheren Malpas Senior furnish enough detail to facilitate the reconstruction of the social and intellectual context in which the younger Katheren performed her possession in early 1621.

Besides betraying the content of one family's perception of contemporary demonology, the circumstances leading to the collapse of the imposture underscore the tension inherent in the scheme as a result of the need for the content of Katheren's possession to conform to both popular and learned 
demonological discourse. In order to establish the possession, the conspirators needed to tailor their fraud to conform to the epistemology of their social and geographic peers. Yet, to make the scheme lucrative, they needed to seduce some of the increasing number of gentry moving into the parish from London. Beyond a fairly standard inventory of symptoms, the understanding of demonology of the two groups imposed competing demands on the demoniac herself: the learned argued that natural causation be eliminated as an explanation for Katheren's behaviour, while her neighbours prompted her to name the witch who tormented her. But it was likely the fact that Thomas sought to engage the services of a number of Puritan ministers to dispossess his granddaughter that brought the matter to the attention of the Attorney General. In a heavily Puritan region like Essex, it is hardly surprising that Thomas sought to use Puritan divines to secure the veracity of the imposture. But possession had been used to great effect as propaganda by both sides of the non-conformist religious spectrum to the detriment of the official church. As a result, the state had imposed a new, more rigorous and exacting burden of proof for demoniacs to meet. Thus, Katheren and her grandmother were examined by the king himself, and then prosecuted in Star Chamber, because the state feared that their charade might be subsumed into the religious and political struggle being waged against the crown for authority in matters of religion.

\section{II}

Elizabeth Saunders admitted that in about December 1620 she persuaded Katheren Malpas the younger to pretend to be possessed; she states that the imposture was her idea alone and that her husband did not find out about it until some time later. In early February 1621, Katheren threw her first fit. According to Elizabeth, Katheren "woulde have a risinge upp in her stomacke to the bignes of a halfe penny loafe \& would beat her heade against the wainscotte <ante correctionem: wall> \& would shrugge up her shoulders $\&$ woulde make her boanes to crackle wi ${ }^{\text {th }}$ in her skyne \& <ante corr: would have > some tymes her mouth would be drawne on one side"(STAC 8 32/13 f. $10^{v}$, q. 4). In her answers, Katheren Senior described her daughter's fits as being consistent with the palsy: she would shake violently and foam at the mouth; her body and limbs would become rigid. Furthermore, the lump in her stomach would periodically shoot visibly across her torso into her neck or her arms (STAC $832 / 13$ f. 1 ${ }^{\mathrm{v}}$, q.4.). 
Compared to the accounts of the fits of other demoniacs presented in the pamphlet literature, Katheren's inventory of symptoms is fairly conventional. Martha Brossier, a French demoniac who was the subject of a brief tract englished in 1599, used to throw herself around, make her body shake, gnash her teeth and contort her face. ${ }^{10}$ Mary Glover, a London demoniac dispossessed by six Puritan preachers in 1602, would toss her head about, shrug up her shoulders and contort her eyes, mouth and hands. Like Katheren, she also suffered torment in her limbs and a curious swelling in her belly. ${ }^{11}$ That this lump in Katheren is described as roving through her person is also consistent with the symptoms of other demoniacs. It was a device used to great advantage by William Sommers, a Nottingham demoniac, in 1598, until a more sceptical bystander discovered that Sommers had effected the illusion simply by moving his clenched fist around under the bed sheets. ${ }^{12}$ In fact, the symptom was sufficiently paradigmatic that during the fraudulent possession scene at the end of The Devil is an Ass (1616), Ben Jonson has the character of Fitzdottrel manufacture the illusion by allowing a mouse held under the sheets to run across his chest. ${ }^{13}$

That the spectacle of Katheren's possession was decidedly similar to cases described in the pamphlet literature suggests that she drew from a widely known and understood inventory of symptoms to craft her imposture. While undoubtedly many of these symptoms have scriptural precedent, the content of demonic fits had become progressively more sophisticated through the sixteenth century. As a result, it was incumbent upon Katheren to supplement these biblical symptoms of possession with current perceptions of demonic behaviour if her imposture was ever to be credited by her neighbours. Indeed, the paucity of scripturally-sanctioned symptoms of possession was recognised by the priests who held seven people captive at Denham in late 1585 , trying to convince them that they were possessed. Sara Williams, one of the victims of this scheme, notes that it was the ordinary custom of the priests to be talking about the fits of the demoniacs they had encountered on the continent. In this way, Sara states, she learned how she could best please her captors and embellished her fits accordingly. ${ }^{14}$ Indeed, the inventory of symptoms was sufficiently well known that Pug, the demon at the centre of Jonson's play, lists a few of the more common ones. He says to Fitzdottrel, "[I will] teach you such tricks, to make your belly swell, / And your eyes turn, to foam, to stare, to gnash / Your teeth together, and to beat yourself, / Laugh loud, and feign six voices." 15 That Jonson specifies such signs as diagnostic of possession in the context of a satire written for public 
performance underscores the fact that there was an expected pattern of behaviour for demoniacs.

In their pleadings, Thomas and Katheren Senior took great pains to point out that they could not tell if the younger Katheren's fits were feigned. While this was arguably their only defence, it does not seem unreasonable to conclude that neither was privy to Elizabeth's scheme at its inception. Katheren Senior was living on Verie Olde Fish Street in the parish of St. Mary Magdalen in London with her husband (STAC, $832 / 13 \mathrm{f} .1^{\mathrm{r}}$ ). In the previous year, she had seen her daughter only once and did not return to see her again until some five or six weeks after the fits began; this would probably have been about the middle of March 1621 (STAC, $832 / 13 \mathrm{f} .1^{\mathrm{v}}$, q. 5). Nevertheless, that she was eventually accused of complicity in the scheme suggests that she was not completely devoid of blame, for the specific accusations of the Attorney-General were based upon the testimony of her daughter during her examination by the king.

Thomas's knowledge of the imposture is a different matter, for his testimony is inconsistent and, at times, defies credulity. In his response to the Attorney-General's interrogatories, Thomas states that he never knew that Katheren counterfeited her possession; in fact, he goes so far as to argue that he had no idea that any suspicion had alighted on Katheren as late as the day before she was summoned before the king (STAC $832 / 13$ f. 4 r, q. 1; f. $5^{r}$, q. 9 ; f. $5^{\text {r }}$, q. 12 and f. $7^{\text {v }}$, q. 22 ) ! His denial does not ring true in the context of his wife's confession, for although Elizabeth Saunders states that Thomas was not involved at the scheme's inception, she makes it clear that he was later a willing participant. However, her testimony is inconsistent about when and how he found out. To fall back again on the interrogatories of the Attorney-General, what seems to have happened is that, at some point early in the imposture, Thomas overheard Elizabeth Saunders chastising Elizabeth Malpas, Katheren's sister, for accusing Katheren of counterfeiting her fits. While Thomas admits that he heard this conversation, only six lines later in his testimony he again denies that he ever knew that Katheren's possession was fraudulent (STAC $832 / 13$ f. 5r, q. 9 and f. 11 r , q. 9). According to the Attorney General, Thomas was initially furious with his granddaughter. Later, though, when he saw many people, including certain "persons of qualitee," coming to visit Katheren and giving her money out of pity, he underwent a profound change of heart (STAC $832 / 13$ f. 9r , q. 10, q.11 and f. 16r).

By the early seventeenth century, there were far more such persons of quality resident in the parish of West Ham. As the population of London grew 
rapidly through the sixteenth century, the resulting overcrowding, with all of the attendant social and sanitary problems, caused an increasing number of the city's affluent to flee to the comparative peace and cleanliness of the near-by countryside. ${ }^{16}$ As a result, the social constitution of West Ham underwent quite a dramatic conversion, as the likes of the wealthy merchant Sir Thomas Lodge and the jurist Sir Edward Coke took up residence in the parish. It is not at all unlikely, then, that Thomas saw Katheren's imposture as an ideal vehicle to exploit this new influx of wealth.

In order to maximise the alms given to her, Thomas, likely with the conscious collusion of Katheren Senior, determined to spread the news that the younger Katheren was "stranglie visited." According to Elizabeth Saunders, the story was current throughout the parish within three weeks (STAC 8 $32 / 13 \mathrm{f}$. 12 ${ }^{\mathrm{r}}$, q. 14). That the news spread so fast, Daniel Walker argues, was due to the intrinsic appeal cases of possession held for most people; they were common enough to understand but still sufficiently rare to be an exciting novelty. ${ }^{17}$ But to a seventeenth-century public, possession was more than this; in a very tangible sense, it was a manifestation in microcosm of the ultimate struggle between God and the Devil. As such, it was a clear and unambiguous eschatological sign. Indeed, the development of a possession foreshadowed precisely the progression of events leading up to the end of history. The rage and fury of the demon, together with the pain of the demoniac, served to personalise the profound intensity of this ultimate conflict. Thus, cases of demonological possession afforded observers an opportunity to watch a scaled-down enactment of Revelation, complete with its attendant horrors. ${ }^{18}$

\section{III}

Some idea of the intensity that possession aroused in people's minds can be gleaned from the pamphlets written about particularly notable cases. A particularly vivid example of this comes from John Swan, writing in 1603 about the dispossession of Mary Glover. In Swan's narrative, the struggle between the demon and the preachers engaged to pray and fast with Mary comes to assume almost Manichaean proportions. Vividly, Swan portrays the ministers and the audience as praying so that they might see Christ "overcome Leviathan and that he should walk upon the Lion (that seeks to devour us) and adder and tread the young dragon under his feet." 19 But Swan's description of Mary's possession also has an intimacy for its audience, for the struggle takes place in a familiar place, in someone with whom 
the audience can empathise. Indeed, Swan goes to some length to situate the demonic in the context of the mundane; for instance, he mentions that the dispossession occurred at the house of one Mistress Ratcliffe in Shoreditch, and he describes its interior in some detail. Moreover, he records the time each prayer session began and notes the specific effects of the prayers on Mary. ${ }^{20}$ Clearly then, visiting a demoniac was more than a pleasant afternoon's entertainment. It was a manifestation of the ultimate drama, acted out in an individual and situated in a largely familiar context. Stephen Greenblatt argues that the effect of this peculiar blend of intimacy and apocalypticism-in-microcosm was to instil a sense of stunned awe and acute wonder in the minds of those who beheld it. ${ }^{21}$ This awe, he suggests, is a product of the juxtaposition of the demoniac and her environment: the more familiar or apparently mundane the physical setting for the possession, the sharper the juxtaposition with the spectacle. ${ }^{22}$ But to supplement and compound the effects of this juxtaposition in the minds of their viewers, it was important for Thomas and Elizabeth Saunders to provide an interpretative commentary on Katheren's fits. As familiar members of the community, Thomas and Elizabeth worked to explain Katheren's every action within an eschatological framework. They reinforced the domestication of the possession by exploiting their social position and its concomitant parochial networks of trust in a deliberate attempt to suspend the possibility of natural explanation in the minds of those who came to witness the spectacle.

The influence of the concomitant commentary in cases of possession was a problem widely appreciated at the time. In his 1627 Guide to Grand Iury Men, Richard Bernard warned prospective Grand Jurymen against leaving themselves vulnerable to deception; they ought not to be too trusting of reports of possession which came to them second-hand, regardless of the source. Moreover, he shows himself all too familiar with the effect that the peculiar, placed in the context of the mundane, had on its observer, for he stresses that Grand Jurymen should avoid jumping to rash conclusions when first confronted by the full horror and spectacle of a demoniac's fits. ${ }^{23}$ Bernard argues that observers presented with a well-executed dumb-show specifically calculated to elicit awe, together with an interpretative narrative furnished by a known and trusted peer, tend to be all too prepared to suspend rational credulity. As a result, the observer relocates the spectacle within the narrow confines of an eschatological explanatory discourse. The effect of the performance, Bernard laments, is such that, "when people come to see such supposed to be possessed by a Divell or Divels; some are filled with 
fancyfull imaginations; some are possessed with feare; so, as they at first time, on a sudden, thinke they heare and see more then they doe, and so make very strange relations without truth, if they take not time." 24 Again, Jonson's satire underscores this point, for part of the problem with Fitzdottrel's demonic fits is that their authenticity is supported by the learning and reputation of no less a person than a judge. ${ }^{25}$

As the illusion is aggressively manipulated by the performers and commentators, the intensity of the possession grows in the minds of the beholders. It is probably not that those who reported Katheren's possession deliberately embellished the truth; rather, as for the mediaeval author of a saint's life, one or two rather innocuous examples of the fantastic tended to add credence to those more incredible events which have not been directly witnessed. As a result, at least in the immediate environment of the demoniac, rational credulity tends to be impeded by an intellectual filter that favours an eschatological interpretation. All events taking place in and around the possessed party must now pass through this filter; thus, coincidences and otherwise mundane events come to be invested with a significance they would otherwise lack. With the "fact" of possession proven in the minds of her audience and those who heard about it from familiar and hitherto trusted sources, every action in the immediate physical vicinity of the demoniac is invested with eschatological significance.

\section{IV}

As the size of her audience grew and she became more comfortable in her performance, Katheren began to embellish her fits on her own. For example, when a bible or religious book was brought to her, she would fling it across the room. Although Elizabeth Saunders denied that Katheren announced that her devil would not suffer her to read it, this was clearly what her audience was supposed to think. Indeed, Elizabeth herself admits that Katheren's actions were consistent with one possessed by an evil spirit (STAC 8 32/13 f. $11^{\mathrm{v}}$, q. 12; f. $18^{\mathrm{r}}$ and f. $6^{\mathrm{r}}$, q. 15). Interestingly, Katheren Senior, Thomas and Elizabeth all deny having taught her to do this; given Elizabeth's apparent willingness to confess to helping her refine other aspects of her performance, there seems little reason to doubt this testimony.

That Katheren made this innovation herself is highly significant; for, just as her fits and their interpretation combined to suspend disbelief in her audience, so she had to tailor her performance to conform to their expectations. Casting aside Scripture and prayer books was a common feature in 
many possessions, ${ }^{26}$ thus, where this symptom was absent, the audience would demand that it be tested. It would be quite clear to the demoniac how she ought to react. It is as if the dynamic between the demoniac and her audience privileges only a very limited interpretation of events, for when the demoniac claims something beyond the confines of the explanatory discourse, the audience tends to demand a measure of reinterpretation. For instance, when Helen Fairfax thought that she saw a vision of God in the course of one of her fits, her family tried to convince her that she was actually being deceived by her devil. As a result, when the same vision recurred four days later, horns sprouted from the head of her previously beatific vision. ${ }^{27}$ A vision of God was not consistent with her audience's perception of the course of possession, and so they demanded it be reinterpreted; the demoniac obliged.

Counterfeit possession, then, was akin to Commedia dell' arte: the demoniac had to work within an accepted framework that had been developed and refined over time. She had to draw on a traditional inventory of symptoms, which owed as much to the sensational accounts of possession described in the pamphlet literature as they did to popular belief or Scripture. Although the specific dialogue was left unwritten, the progression of the imposture was predetermined by tradition and by its inherent apocalypticism.

As persons of quality from the wider parish began to descend on their modest dwelling, Thomas realised that the interpretative commentary furnished by the Saunders family alone was no longer adequate. If the imposture was to be maintained in the minds of a more learned and wealthy audience, it was vital to secure an independent interpretative commentary from one of greater social or intellectual repute. To this end, Katheren Senior petitioned the Bishop of London for a licence to hire preachers to pray with her daughter (STAC $832 / 13$ f. 6r , q. 16 and f. 2v, q. 16).

Dispossession had been a controversial issue since the middle of the sixteenth century when exorcism was removed from the English rite. ${ }^{28}$ Although the state church considered it to be an idolatrous ceremony without biblical sanction, the demand for spiritual relief from supernatural affliction did not cease. Indeed, the public nature of exorcisms made them ideal vehicles for Catholic propaganda; once the notion of possession was securely implanted in the minds of the audience, successful dispossessions became moving testimonies to the power of the true faith. As Samuel Harsnett notes, this is precisely what the Jesuits did at Denham after convincing seven 
youths that they were possessed. In front of large audiences, these Jesuits demonstrated how the demoniacs could not endure the sight of priests or relics, how they could not cross themselves and how they would cry out when holy water was poured on them. ${ }^{29}$ As a result of the devil's apparent distress when confronted with such overtly Catholic trappings, Harsnett argues that some four to five thousand people were reconciled to the Roman usage. ${ }^{30}$

To counter such Catholic successes, the Puritans also turned their attention to dispossession. Rather than staging formal exorcisms, however, the Puritan propagandists seized upon the account in the Gospel of Mark where Christ relieved a possessed youth of an evil spirit through prayer and fasting (Mark 9: 14-29). While prayer and fasting did not actually command God to dispossess the demoniac, the practice provided a measure of relief, insofar as it accorded with God's glory and the good of the possessed. ${ }^{31}$ As the Puritans drifted further from the state church, dispossession by such means came to be construed as a means of validating Puritanism. And, as it did for the Catholics, the devil's discomfort during a dispossession won the Puritan programme much popular support. For the state church, then, dispossession was an issue which could not easily be divorced from politics.

Indeed, the political subtext to the debate was clearly underscored in the late autumn of 1602 with the possession of Mary Glover. Mary, the teenage daughter of a London shopkeeper, accused one Elizabeth Jackson of bewitching her. The publicity around Jackson's subsequent trial polarised religious sentiment in London. The state, through Dr. Edward Jorden, tried to assert that Mary's illness was natural. However, when asked by Judge Anderson to prove conclusively that this was actually the case, the doctor was unable to do so. Consequently, Anderson gave the benefit of the doubt to the preternatural and convicted Jackson. With the veracity of Mary's possession established at law, six Puritan preachers sought immediately to capitalise on the notoriety of the case and succeeded in dispossessing her in front of an enthusiastic audience of potential converts in December 1602. ${ }^{32}$

It was to prevent another such defeat in the propaganda war against the Puritans that the state church issued Canon 72, in the 1604 Constitutiones sive Canones Ecclesiastici, outlawing dispossession by prayer and fasting without a licence granted from a diocesan bishop under pain of excommunication. ${ }^{33}$ As bishops were generally none too sympathetic towards the Puritan agenda, this canon amounted to an attempt to end the use of dispossession as religious propaganda. Within this context, then, it is very 
peculiar that Bishop King granted Katheren Senior a licence to secure preachers.

Thomas and Katheren Senior used this licence to procure the services of Mr. Jennings, the Vicar of West Ham, and one Mr. Holbrooke, described as the parish lector. While the sources are silent about Jennings, William Holbrooke was a popular and outspoken Puritan preacher and, as a result, found himself afoul of the ecclesiastical authorities, being put on probation for nonconformity in 1617. But despite his repeated injunctions against unsavoury speech, plays, taverns, bawdy houses, roguish musicians, ballads and wanton sonnets, Holbrooke enjoyed much public esteem; indeed, he was appointed vicar of All Saints' Church in West Ham by popular choice. ${ }^{34}$ Thus, in a scene not unreminiscent of Mary Glover's deliverance, Jennings and Holbrooke, together with Mr. and Mrs. Fawcett, a Mr. Adister and his wife, and a number of other people from the parish, prayed for Katheren's delivery around Easter Week. Elizabeth notes that the size of the audience present was not insignificant (STAC $832 / 13 \mathrm{f} .11^{\mathrm{v}}$, q. 13).

Although all that is known about Samuel Adister is that he was acquitted of stealing a horse worth $£ 9$ in $1622 .{ }^{35}$ William Fawcett seems to have been a man of somewhat better repute. Though a resident of Upton, Fawcett was born in Yorkshire and had previously lived in London. As such, he was the epitome of the new gentry who were beginning to immigrate to West Ham. $\mathrm{He}$ was wealthy but with strong religious and social convictions. For instance, he endowed an elementary school and paid for two of his relatives to take degrees in theology at Cambridge. Moreover, he was rabidly antiCatholic, for in his will, proved in 1631 , he left the rent of $£ 210$ s. from a house in Upton to provide for an annual sermon on the anniversary of the gunpowder plot. Indeed, the epitaph on the monument his wife had erected to him in All Saints' Church in West Ham describes him as "a prime mover of a perpetual annual celebration of the miraculous deliverance of the country and religion from the abominable, heinous, and fiery treachery of the Papists"; it concludes by stating that "he practised the greatest piety, he promoted peace, he enriched his relations." 36

Fawcett and Holbrooke must have been exactly the kind of people Coventry feared might become interested in Katheren's imposture. They were popular, earnest and influential. From the perspective of the state, were such men to place their reputations behind the interpretative commentary developing around the would-be demoniac, the pretence of a labouring family might become the touch-paper for another divisive national debate. 
Consequently, Coventry was concerned with determining how public these sessions of prayer were (STAC $832 / 13 \mathrm{f} .15^{\mathrm{r}}$, q. 13; $c f . \mathrm{f} .9^{\mathrm{r}}$, q. 16). In fact, with Holbrooke also preaching at Bromiey in Middlesex and St. Andrew Hubbard in London in 1621, and with possession being such a useful vehicle for propaganda, news seems to have spread quite rapidly through the Puritan community, with the result that, on several other occasions after Holbrooke's second visit to Katheren, people who "wore blacke clothes like unto ministers" came to pray with Katheren (STAC $832 / 13$ f. 2v, q. 16). While to Coventry this meant that the interests of the Puritans had been piqued by the events in Upton (STAC $832 / 13$ f. 9r , q. 16; $c f$. f. $18^{\text {r }}$ ), to Thomas it meant an increase in revenues.

It was at this point that the emerging tension between popular and learned discourses first became problematic for Thomas, for he engaged the services of one Mr. Franklin, dwelling at Ratcliffe Highway. Though Thomas described Franklin as a "phisicione," Holbrooke and Adister laboured to persuade him that Franklin "did deale \& use sawcerie" (STAC 8 32/13 f. 5r, q. 12). It would seem, then, that Franklin was a cunning man. As Macfarlane has argued, the consultation of a cunning man was a vital step in the social diagnosis of supernatural activity. He would inquire about the nature of the affliction and then seek to discover the social relationships of the victim and any suspicions they might harbour. Thus cunning men tended to lend the prejudices and suspicions of the victim some social validity. ${ }^{37}$ Indeed, Bernard underscores this point, lamenting how easily cunning men were able to confirm and manipulate people's suspicions of the supernatural. ${ }^{38}$ That this is precisely the result Thomas sought is confirmed by his wife's reaction. Appalled that Thomas had spent twenty shillings for Franklin's services, Elizabeth chastised Thomas, saying, "Gods bread, Tom Saunders why wouldest thou give this fellowe money being thou knowest she counterfits" (STAC $832 / 13$ f. 9r , q. 13; $c f$. f. 5v , q. 13). Clearly, then, Thomas did not squander such a sum securing Franklin's services for medical reasons.

However, while a cunning man may have been useful to the family in manipulating popular sensibilities, such sorcery risked alienating their Puritan supporters. Thus, Thomas acquiesced in Holbrooke's concerns and did not consult Franklin again. Instead, in an analogous move directed at his social superiors in his audience, Thomas sought to champion supernatural causation by being seen to rule out affliction from disease. To this end, a preacher who lived on Lambeth Hill was dispatched to Dr. Theodore Gulston of Black Friars with a sample of Katheren's urine. Gulston, a fellow of the 
College of Physicians, prescribed some manner of drink for Katheren; unsurprisingly, it did her no good (STAC $832 / 13$ f. 5r., q. 12). ${ }^{39}$

While the supernatural was still far from being completely eliminated as an explanatory strategy for the peculiar, among the more learned there was a growing consensus that it could no longer be de facto assumed without first concretely ruling out the possibility of disease. In this context, Edward Jorden's A Disease Called the Suffocation of the Mother marks a turning point. Composed in 1603 in the wake of his involvement in the Mary Glover case, Jorden's tract stressed that many natural diseases could easily be falsely diagnosed as possession. In an attempt to establish a new foundation for the epistemology of causation, Jorden stressed that a natural explanation should be assumed, if possession could not be clearly proven. ${ }^{40}$ In effect, this amounted to a reversal of the burden of proof championed by Judge Anderson in the Glover case. A quarter of a century later, after noting a similar array of natural diseases which could be mistaken for possession, Bernard advised his prospective Grand Juryman to "be inquisitive of the grounds leading the Complaint, why he thinketh himselfe, or any of his, to be bewitched? whether it bee not rather from his owne feare, than from any other cause? or whether the affliction bee not from some naturall cause?"41 Clearly, then, the content of the learned discourse of causality was beginning to change. The supernatural could no longer simply be assumed where rational explanation proved deficient. As he was seeking the patronage of the wealthy and learned, it was important for Thomas to be seen to be attempting to rule out natural causation.

\section{V}

As a result of their efforts to consolidate the veracity of the imposture for both their parochial and more learned audiences, the strange happenings in Upton began to acquire some notoriety and momentum of their own, for sizeable audiences began to descend upon the Saunders' house to see the demoniac. To capitalise on this, Thomas ordered that those coming to see Katheren "should not be permitted to have accesse unto her with out givinge money therefore or promisinge to give" (STAC $832 / 13$ f. $9^{\text {r }}$, q. 17). To this end, he and "some others often tymes [did] sitt att the ante door of the house where in the said Katheren Malpas soe remayned to keepe people from going into the said house" (STAC $832 / 13 \mathrm{f}$. 9r, q. 17). In short, they underscored the theatricality of their charade by charging admission. ${ }^{42}$ 
However, it is at this point that the tension resulting from the need to marry popular and learned demonological discourse began to wrench the scheme asunder, for the demands of the former forced Katheren to accuse Elizabeth Hedlyn and Goodwife White, both of West Ham, of invoking the evil spirits that possessed her. In the context of popular discourse, possession and witchcraft were inextricably linked. Keith Thomas goes so far as to argue that "possessed" and "bewitched" were effectively synonymous in the seventeenth century. Most of the noted demoniacs of the period were able to accuse someone of bewitching them. Again, this is a point about which Bernard warns his Grand Jurymen, urging them to resist the temptation to assume such a causal nexus. ${ }^{43}$ Within the eschatological discourse into which Thomas, Elizabeth and Katheren Senior had worked so hard to situate the younger Katheren's actions, it would have been virtually impossible for the latter to maintain her facade without presenting her audience with at least some clue as to the identity of her tormentor.

While the records are silent about White and Hedlyn, it is likely that these women would largely fit Harsnett's description of the archetypal witch, as the success of the charge was contingent upon how well it conformed to social expectations. Though Harsnett characterised those who believed in witches as either children, fools, women or cowards, melancholy or senile, he argues that the quintessential witch was "an olde weather-beaten Croane, having her chinne and her kness meeting for age." 44 Macfarlane's study of Essex Assize indictments adds that the perception of a witch's guilt was also a function of her social background, character, parents and status in the community. ${ }^{45}$ In this context, it is interesting that Thomas does not seem to have known Goodwife Hedlyn, for he admits that he had to ask a smith called Palmer, who lived in Plaistow, where she lived (STAC $832 / 13 \mathrm{f} .7^{\vee}$, q. 21). This suggests that the accusation against Hedlyn was not motivated by any real or imagined slight; rather, the accusation was a cynical attempt to exploit the reputation of a marginal figure in the parish to the advantage of the imposture. It was consciously calculated to conform to the expectations of the audience.

Katheren seems to have known Goodwife White, unlike Hedlyn, for upon hearing of the accusation against her, White immediately came to visit Katheren. Confronted thus, Katheren withdrew her accusation, claiming only that she had been mistaken (STAC $832 / 13 \mathrm{f} .6^{v}$, q. 18). The would-be demoniac continued in her charge against Hedlyn, though, proclaiming to her audience that Hedlyn often visited her in the likeness of a brown dog, 
which roared and foamed at the mouth, or in the form of a cat. Both of these were fairly conventional images with much precedent. More unusually, Katheren accused Hedlyn of once coming to her in the guise of a swarm of bees (STAC $832 / 13$ f. 6rv , q. 18 and f. 3r , q. 18).

In a cowardly attempt to support this accusation against Hedlyn, at some point in late March or early April 1621, Thomas visited Anne Godfrey, the wife of Eli Godfrey, a yeoman in the ward of Plaistow. Anne had been quite ill the previous December and, pressured by Thomas, became convinced that her illness was caused by Hedlyn's witchcraft. He then persuaded her to come and see Katheren during one of her fits. Immediately afterwards, Anne took to her bed and did "feigne her selfe to be sicke and to practise \& exercise the like trickes \& devises as the said Katheren Malpas did" (STAC 8 32/13 f. $9^{r}$, q. 19).

On 7 April, a mere three days after Anne had begun her fits, Thomas convinced her to swear out a complaint against Hedlyn at the Quarter Sessions. Though the Attorney General argued that Thomas was heard to remark that "it was time to have the witch cutt of ff]" (STAC $832 / 13 \mathrm{f}$. 9v, q. 21), he was loath to swear out his own complaint. However, Anne's complaint seems not to have convinced the presenting jury, for instead of an indictment against Hedlyn at the July Assizes, what is extant is an indictment against Anne herself. ${ }^{46}$ She is accused of pretending to be bewitched by Hedlyn and then falsely and maliciously accusing her of this felony in order to put her in peril of her life. Appended to the bottom of the indictment is a record of the court's verdict. She was found guilty and sentenced to be placed in the stocks at Chelmsford and Barking for two hours, then committed to the house of correction until the next Assizes. ${ }^{47}$ This amounted to a sentence of eight months incarceration.

\section{VI}

Why the charge against Hedlyn ended up backfiring on Anne is an open question; nevertheless, a close reading of the assize file is suggestive. While the frequency of successful indictments framed to fall under the purview of the witchcraft statute of 1604 was declining in Essex under James, some sixty-one such indictments, accusing twenty-eight different people, were levelled at the assizes. Of these, twenty-three indictments were for murder by witchcraft, with a further twenty-four citing witchcraft as the cause of personal injury. The remaining fourteen fall under the broad heading of maleficium. Of the twenty-eight accused, eleven had only a single indictment 
levelled against them, and, of these, all but one were acquitted. Of the remaining seventeen, who had multiple accusations for witchcraft-related offences presented against them, nine were convicted and seven acquitted. ${ }^{48}$ This suggests that trial juries, composed of freeholders and, at times, lesser gentry as well, were decidedly reticent to convict under the witchcraft statute when only a single instance of supernatural activity was alleged. Only when there was a more sustained pattern of witchcraft apparent through multiple independent accusations were trial juries prepared to convict at a rate approaching that of other felonies. ${ }^{49}$ Indeed, accusations made by unconnected demoniacs impressed even the usually sceptical Bernard. ${ }^{50}$ In this context, it is hardly surprising that Anne's lone accusation against Hedlyn broke down: a presenting jury composed of her social superiors needed a more manifest case. What is unclear is why Thomas did not himself swear out a complaint against Hedlyn.

With Anne convicted, Katheren's imposture was increasingly compromised. Though she managed to maintain it through the summer, in the autumn of 1621 she was summoned to Theobald's to be examined by the king. ${ }^{51}$ Understandably, Thomas was very concerned; according to the Attorney General, he feared that if any of them should confess, Hedlyn would have good cause for legal action against them, leaving them "stript out of all and utterly undon" (STAC $832 / 13 \mathrm{f}$. 9v, q. 23). Although no record of such an action is extant, Thomas's fears were not unrealistic; those who levelled indictments that were stamped ignoramus by the presenting jury often found themselves subsequently accused of slander. ${ }^{52}$

Elizabeth accompanied Katheren to the examination but seems to have feared the king more than her husband; both of them broke down immediately and confessed the whole charade. Upon getting word of this, Thomas contemplated flight. In the end, though, he lacked the will to follow through (STAC $832 / 13$ f. 9v , q. 23). In February 1622, Thomas and Katheren Senior were summoned to answer the questions of the Attorney General. This they did through the spring and into the summer. Unfortunately, though, no record of the verdict of the court is appended to the pleadings of the parties. ${ }^{53}$

\section{University of Toronto}

\section{Notes}

1. I am grateful to Lara Hinchberger, Prof. K. Bartlett, and Elizabeth Schoales for their comments on earlier drafts of this paper. 
2. Star Chamber records are housed in the Public Records Office, London. In the nineteenthcentury, a page number was stamped onto the top right-hand comer of each sheet of the pleadings; for the sake of convenience, I have used these numbers in citations. Where individual pages have been subdivided into questions, question numbers are also identified.

3. It is impossible to determine exactly how old the younger Katheren Malpas was at this point. The only indication of her age comes from the Attorney General, who describes her simply as "a younge mayden" (STAC $832 / 13 \mathrm{f} .18$ ).

4. See S. Clark, Thinking with Demons: The Idea of Witchcraft in Early Modern Europe (Oxford: Clarendon Press, 1997), pp. 390-400, and R. Biggs, "'Many Reasons Why': Witchcraft and the Problem of Multiple Explanation," in J. Barry, M. Hester and G. Roberts, eds., Witchcraft in Early Modern Europe (Cambridge: University Press, 1996), pp. 49-63.

5. J. S. Cockburn, Calendar of Assize Records: Home Circuit Indictments Elizabeth I and James I: Introduction (London: H.M.S.O., 1985), p. 98. Cf. The Examination and Confession of Certaine Wytches at Chelmsforde in the Countie of Essex (London, 1566).

6. J. S. Cockburn, "Early Modern Assize Records as Historical Evidence," Journal of the Society of Archivists 5 (1975): 221-28.

7. A. Macfarlane, Witchcraft in Tudor and Stuart England: A Regional and Comparative Study (New York: Harper and Row, 1970), passim.

8. For the mechanics of Star Chamber procedure, see T. G. Barnes, "Star Chamber Mythology," American Journal of Legal History 5 (1961): 8-10; T. G. Barnes, "Due Process and Slow Process in the Late Elizabethan and Early Stuart Star Chamber," American Journal of Legal History 6 (1962): 228-29; and R. Crompton, Star-Chamber Cases, shewing what causes properly belong to the cognizance of that court (London, 1630).

9. These are STAC 8 58/5, STAC 8 207/21, STAC $8213 / 7$ and STAC 8 32/13. Cf. Macfarlane, Appendix I, pp. 301-2.

10. A True Discourse upon the Matter of Martha Brossier of Romorantin, pretended to be possessed by a Devill, trans. Abraham Hartwel (London, 1599), pp. 4, 6 and 15.

11. J. Swan, A True and Briefe Report of Mary Glovers Vexation and Her Deliverance by Fastings and Prayer, in M. MacDonald, ed., Witchcraft and Hysteria in Elizabethan London: Edward Jorden and the Mary Glover Case (London: Routledge, 1991), pp. 16-17, 37 and 43.

12. See D. P. Walker, Unclean Spirits: Possession and Exorcism in France and England in the Late Sixteenth and Early Seventeenth Centuries (Philadelphia: University of Pennsylvania Press, 1981), pp. 61-68, and Stephen Greenblatt, Shakespearean Negotiations: The Circulation of Social Energy in Renaissance England (Oxford: Clarendon Press, 1988), p. 104.

13. Ben Jonson, The Devil is an Ass, ed. Peter Happé (Manchester: Manchester University Press, 1994), 5.5.140-44.

14. S. Harsnett, A Declaration of Egregious Popish Impostures, in F.W. Brownlow, ed., Shakespeare, Harsnett and the Devils of Denham (Newark: University of Delaware Press, 1993), p. 346.

15. Jonson, 5.5.24-27. 
16. P. Corfield, "Urban Development in England and Wales in the Sixteenth and Seventeenth Centuries," in J. Barry, ed., The Tudor and Stuart Town: A Reader in English Urban History, 1530-1688 (London: Longman, 1990), pp. 39-42.

17. Walker, p. 4.

18. See Clark, pp. 393 and 404-9.

19. See Swan, passim, esp. p. 43, and M. MacDonald, Introduction, Witchcraft and Hysteria, ed. M. MacDonald (London: Routledge, 1991), p. xxxviii.

20. Swan, passim.

21. Greenblatt, p. 103.

22. Ibid.

23. Richard Bernard, A Guide to Grand Iury Men (London, 1627), pp. 40-41.

24. Ibid., p. 39.

25. Jonson, 5.8.28.

26. See, for instance, A True Discourse upon the Matter of Martha Brossier, p. 6, and Bernard, p. 31 .

27. E. Fairfax, Daemonologia: A Discourse on Witchcraft as it was Acted in the Family of Mr. Edward Fairfax of Fuyston, in the County of York in the Year 1621, ed. W. Grainge (Harrogate, 1882), pp. 62-64.

28. MacDonald, esp. pp. xix-liv.

29. See Harsnett, p. 222.

30. Ibid., pp. 335 and 390.

31. See The Works of William Perkins, ed. I. Breward (Appleford: Sutton Courtney Press, 1970), pp. 608-9.

32. This is recounted in great detail in Swan, passim.

33. Constitutiones sive Canones Ecclesiastici, per Episcopum Londinensem (London, 1604).

34. P.S. Seaver, The Puritan Lectureships: Politics of Religious Dissent 1560-1662 (Stanford: Stanford University Press, 1970), p. 83, and W.R. Powell, "West Ham," A History of the County of Essex, vol. 6, ed. W. R. Powell (London: Oxford University Press, 1973), p. 116.

35. Indictments at the assizes were made on small membranes of vellum. These are now found bound into bundles at the Public Record Office. Adister's indictment can be found at ASSI $3561 / 1$ m. 19

36. F. Chancellor, Ancient Sepulchral Monuments of Essex: A Record of Interesting Tombs in Essex Churches, and Some Account of the Persons and Families Connected with Them (London, 1890), pp. 377-78, and Powell, p. 161.

37. MacFarlane, pp. 115-23.

38. Bernard, pp. 19-20 and 81-83.

39. "Goulston or Gulston, Theodore, M.D. (1572-1632)," Dictionary of National Biography.

40. E. Jorden, A Disease Called the Suffocation of the Mother (London, 1603), passim. 
41. Bernard, p. 24.

42. How much the scheme actually garnered for them is uncertain, for the defendants contradicted each other in their answers. Thomas said that he received only four pence. Katheren Senior said that the total received was not more than ten shillings and with this Elizabeth agreed (STAC $832 / 13$ f. $1^{\mathrm{r}}$, q. 3; f. $4^{\mathrm{r}}, \mathrm{q}$. 3). It is likely that the scheme must have netted them quite significantly more if Thomas was prepared to spend twenty shillings to engage Franklin and pay Gulston's fees.

43. Bernard, p. 53.

44. Harsnett, pp. 308-9; Macfarlane, passim, esp. p. 17; and K. Thomas, Religion and the Decline of Magic (Harmondsworth: Penguin, 1971), pp. 521-51.

45. MacFarlane, p. 17.

46. ASSI $3563 / 7 \mathrm{~m} .1$.

47. ASSI $3563 / 7$ m. 1. Cf. Calendar of Assize Records, James I, no. 1596, p. 251.

48. This figure includes Robert Parker, who was charged with murder and two counts of inflicting injury through witchcraft but was convicted on the lesser charge of sorcery. Anne Jonn died before her case was tried (Calendar of Assize Records, James I, no. 843, p. 131, and no. 742, p. 114).

49. J. G. Bellamy, The Criminal Trial in Later Medieval England: Felony before the Courts from Edward I to the Sixteenth Century (Toronto: University of Toronto Press, 1998), p. 95. On the composition of juries, see J. S. Cockburn, A History of English Assizes, 1558-1714 (Cambridge: Cambridge University Press, 1972), pp. 113 and 118. Cf. Bellamy, p. 99

50. Cockburn, Calendar of Assize Records: Introduction, p. 92. Cf. ASSI 35 45/1 m. 18a. Bernard, pp. 170-71.

51. Despite his earlier literary endeavours to the contrary, James I took a personal interest in seeking out and disproving cases of possession because the issue had been closely tied to non-conformist propaganda and inextricably linked to state security. Bernard notes with approval how "our late King Iames, by his wisedome, learning, and experience, [was able to] discover divers counterfeits" (p. 34).

52. C. L'Estrange Ewen, Witchcraft in the Star Chamber ([n.p.], 1938), p. 9.

53. Barnes has argued that in every Star Chamber case in which at least one of the defendants was convicted and a fine levied, a note of this fine can be found in the Exchequer Memoranda Rolls. These I have checked for 1622 and 1623 , but I have been unable to find any record of such a fine; it does seem implausible, though, given the evidence and the testimony of Elizabeth Saunders, that Thomas was able to escape any punishment. 